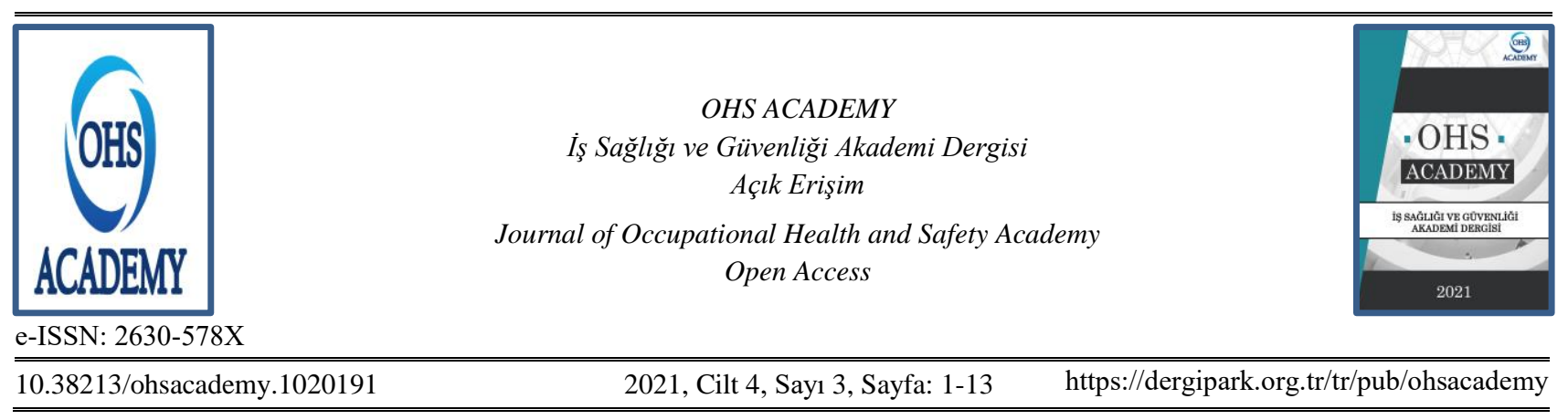

\title{
Bazı Balıkçı Teknelerinde İş Sağlığı ve Güvenliği
}

\author{
Hüseyin Gökhan AYTEPE ${ }^{1}$, Orkun DALYAN ${ }^{2 *}$, Hatice DALYAN ${ }^{3}$, Mehmet PIŞKIN $^{4 *}$ \\ 1,2,3 İş Sağlığı ve Güvenliği Bölümü, Lisansüstü Eğitim Enstitüsü, Çanakkale Onsekiz Mart Üniversitesi, \\ Çanakkale, Türkiye \\ ${ }^{4}$ Gıda İşleme Bölümü, Teknik Bilimler Meslek Yüksek Okulu, Çanakkale Onsekiz Mart Üniversitesi, \\ Çanakkale, Türkiye
}

\begin{abstract}
Makale Tarihçesi
Gönderim: $\quad 07.11 .2021$

Kabul: $\quad 26.12 .2021$

Yayım: $\quad 31.12 .2021$

Araştırma Makalesi

Öz- Balık avlama faaliyetleri tehlikeli ișler olarak sınıflandırılmakta ve iş kazalarına neden olabilecek çeşitli risk faktörlerini barındırmaktadır. Bu nedenle balık avlama faaliyetlerinde kullanılan balıkçı teknelerindeki tehlikelerin azaltılmasına yönelik çalışmalar yapılmalıdır. Bu çalışmada, Çalıșma ve Sosyal Güvenlik Bakanlığı'nın 'Balıkç Gemilerinde İş Sağlığı ve Güvenliği Kontrol Listesi’ araştırmaya katılan altı balıkçı teknesine göre uyumlaştırılarak kullanılmıştır. Araştırma verileri Elmeri gözlem yöntemi ile uygulanmış ve balıkçı teknelerinin güvenlik endeksleri oluşturulmuştur. Kategorilere göre ortalama Elmeri güvenlik endeks değerleri sırasıyla makine dairesi için \%90, kullanılan ağları atma ve sarma operasyonu için \%89, yatakhane için $\% 87$, gemi güvenliği için \% $\% 6$, ağ makarası ile yapılan faaliyetler için \%83, vinç ve halat ile yapılan faaliyetler için \%83, kaptan köşkü için \%80, güvertedeki genel çalışmalar için \%78, yakalanan balığın taşıyıcı gemiye alınması ya da limana çıkarılması için \% $\%$, hasarlı donanımın tamiri için \%77, gemi mutfağı/lavabo kullanımı için \%77, geminin iskeleye bağlanması için \%75, gemiye biniş ve inişler için \%58 olarak bulunmuştur. Bu sonuçlar, literatürde farklı bilimsel metotlar kullanılarak yapılan çalışmalardaki sonuçlarla karşılaştırılarak tartışılmış olup tüm sanayii sektörlerinde kullanılan Elmeri gözlem yönteminin balıkçı teknelerinde de kullanılabileceğini göstermektedir.
\end{abstract}

Anahtar Kelimeler - Balık avlama, Çanakkale, elmeri gözlem yöntemi, iş sağlığı ve güvenliği, risk

\section{Occupational Health and Safety on Some Fishing Boats}

\author{
Hüseyin Gökhan AYTEPE ${ }^{1}$, Orkun DALYAN ${ }^{2 *}$, Hatice DALYAN ${ }^{3}$, Mehmet PIȘKIN ${ }^{4 *}$ \\ 1,2,3 Occupational Health and Safety Department, School of Graduate Studies, Çanakkale Onsekiz Mart \\ University, Çanakkale, Türkiye \\ ${ }^{4}$ Food Processing Department, Vocational School of Technical Sciences, Çanakkale Onsekiz Mart University, \\ Çanakkale, Türkiye
}

\begin{abstract}
Article History
Received: $\quad 07.11 .2021$

Accepted: $\quad 26.12 .2021$

Published: $\quad 31.12 .2021$
\end{abstract}

\section{Research Article}

\begin{abstract}
Fishing activities are classified as dangerous jobs and contain various risk factors that can cause occupational accidents. For this reason, studies should be carried out to reduce the dangers in fishing boats used in fishing activities. In this study, the "Occupational Health and Safety Checklist on Fishing Vessels" of the Ministry of Labor and Social Security was used by adapting it to the six fishing boats participating in the research. The research data were applied with the Elmeri observation method, and the safety indexes of the fishing boats were created. The average Elmeri safety index values by categories are $90 \%$ for engine room, $89 \%$ for throwing and winding operation of used nets, $87 \%$ for dormitory, $86 \%$ for ship safety, $83 \%$ for activities with net reel, activities with crane and rope, $83 \%$ for the bridge, $80 \%$ for the bridge, $78 \%$ for general work on the deck, $78 \%$ for taking the caught fish aboard or porting, $77 \%$ for repairing damaged equipment, $77 \%$ for galley/sink use, for mooring the ship to the pier $75 \%$ was found to be $58 \%$ for embarkation and disembarkation. These results are discussed in comparison with the results of studies using different scientific methods in the literature and show that the Elmeri observation method, which is used in all industrial sectors, can also be used in fishing boats.
\end{abstract}

Keywords - Fishing, Çanakkale, elmeri observation method, occupational health and safety, risk

${ }^{1}$ gokhan.aytepe@gmail.com (D) Orcid id: 0000-0002-9616-4776

2 orkundalyan@outlook.com (D) Orcid id: 0000-0003-4791-9084

${ }^{3}$ haticedalyan8789@gmail.com (D) Orcid id: 0000-0002-3012-742X

4 mehmetpiskin@comu.edu.tr (D) Orcid id: 0000-0002-4572-4905

*Sorumlu Yazar / Corresponding Author: orkundalyan@outlook.com, mehmetpiskin@ comu.edu.tr, Çanakkale Onsekiz Mart Üniversitesi Teknik Bilimler Meslek Yüksek Okulu 


\section{Giriș}

İş sağlığı ve güvenliği (ISG) konusunda farkındalık oluşturmak ve bu farkındalığın güvenlik kültürüne dönüştürülmesi için ISG politikalarının uygulanması yüksek derecede öneme sahiptir. İşyerindeki tehlikeler hakkında doğru bilgilerin toplanması, çalışma ortamının gözetimi ve iyi uygulama örneklerinin değerlendirilmesi İSG kültürü için gereklidir (ÇASGEM, 2017). İş kazası ve meslek hastalıkları nedeniyle her yıl ortalama 2,7 milyondan fazla kişi hayatını kaybetmektedir (Öçal ve Çiçek, 2017). Bir iş kazasının meydana gelmesi için birden fazla katmanın başarısız olması gerekir (Bansal ve Selvik, 2021). Bu katmanlar prosedür, talimat ve kontrol olarak isimlendirilebilir. Yetersiz işletim prosedürleri, talimatları ve denetim eksikliği bir iş kazası olasılığını artırır (Paolo vd., 2021). İş kazalarının nedenlerinin \%88'lik kısmı hatalı davranışlarından kaynaklanmaktadır (Dalyan vd., 2021a). Davranış odaklı İSG uygulamaları, hatalı davranışların çalışan tarafından fark edilmesi ve olumlu yönde değiştirilmesini sağlamaktır (Nişancı ve Demirören, 2020). Davranışlardaki olumlu yönde değişimin devamlılığını sağlamak için sağlıklı ve güvenli iş yerlerinin teşvik edilmesi bir öncelik olmalıdır (Bilir, 2016). Sağlıklı ve güvenli iş yerleri ise güvenlik kültürü ile var olabilir. İş Sağlığı ve Güvenliğinin sadece iş kazalarına odaklandığı düşünülse de güvenlik kültürünün tanımı tüm yaşamı kapsamaktadır (Dalyan vd., 2021b). İşyerlerinde güvenlik kültürünün yaygınlaştırılmasında İSG eğitimleri önemli bir etkendir (Dalyan ve Pişkin, 2020). İş kazalarının nedenleri hakkında literatürde bir çok araştırma mevcuttur. Heinrich (1959), kazaların \%88'inin güvensiz davranışlardan, \% 10'unun güvensiz ortamlardan ve \%2'sinin de önlenemez durumlardan kaynaklandığını ortaya koymuştur. Camkurt (2007), tarafından yapılan başka bir araştırmada kazaların \%95'ninin güvensiz davranış ve kişisel koruyucu donanımın kullanılmamasından, \%5'nin ise teknik nedenlerden kaynaklandığını tespit etmiştir.

Su ürünleri, dünya besin gereksiniminin büyük bir kısmını karşılamaktadır. Denizlerden ve iç sulardan besin elde etmenin en temel yolu balıkçılık faaliyetleridir (Bütüner, 2008). Türkiye Karadeniz de dahil olmak üzere Akdeniz sular sistemi ile çevrili önemli bir deniz ülkesidir. Dünya toplam deniz yüzeyinin \%0,8'ini kapsayan yaklaşık 300.000 kilometrekarelik yüzey alanına sahip yarı kapalı, oligotrofik olarak tanımlanan bu sistemin önemli bir ekolojik parçasını Türkiye oluşturmaktadır (Estrada, 1996). Günümüzde balık avlanma faaliyetlerindeki en önemli araçlarından biri balıkçı gemileridir. Türkiye'de Balık avlama faaliyetinde kullanılan tekneler,1380 Sayılı Su ürünleri Kanunu ve 618 Sayılı Limanlar Kanununa bağlı Limanlar Yönetmeliği ve 4922 Sayılı denizde Can ve Mal Koruma hakkında Kanun hükümlerinde de belirtildiği üzere icra ettikleri avcılık türleri ve gemilerin en, boy, gross ton, inşa malzemesi gibi özelliklerine göre sınıflandırılır. Amaçlarına göre ticari ve sportif olarak da sınıflandırılabilir (Şahin ve Özekinci, 2020). Balıkçı gemileri kullanılan ă̆ ve av aracının türüne göre isimlendirilmektedir. Örneğin; bir balıkçı gemisi voli (alamana) ağı ile avcılık yapıyorsa voli (alamana) teknesi ya da çevirme ağı ile avcılık yapıyorsa gırgır gemisi adını almaktadır. Balık avcılığı mesleği kaza ve ölümlerin sıklıkla yaşandığı bilinmektedir (Perez-Labajos, 2008; Roberts, 2010; Davis, 2012). Denizcilik sektöründe en küçük bir hata yaralanmaya hatta ölüme sebep olabilmektedir (Ulukan, 2016). Bu nedenle, iş kazalarının sıklıkla yaşandığı balık avlama faaliyetleri araştırılması gereken önemli konulardır.

Bu çalışma kapsamında Çanakkale Boğazının sahil kıyı şeridinde balık avlama faaliyeti icra eden 4 adet ruhsat kodu (C) ve (D) olan küçük ölçekli ticari balık avlama teknesi ile 2 adet özel tekne; Çalışma ve Sosyal Güvenlik Bakanlığı İş Sağlığı ve Güvenliği Uzmanlık tezinde (Tantoğlu, 2016) belirtilen Balıkçı Gemilerinde İSG Kontrol listesinin revize edilmesiyle kontrol edilmiştir. Balık avlama faaliyetlerinin Elmeri gözlem yöntemi ile irdelenmesi, ilerleyen dönemde yapılacak olan bilimsel çalışmalara katkı sağlayarak bilim insanlarına yol göstereceği düşünülmektedir.

\section{Materyal ve Yöntem}

Araştırmada, Çalışma ve Sosyal Güvenlik Bakanlığı İş Sağlığı ve Güvenliği Uzmanlık tezinde (Tantoğlu, 2016) belirtilen 'Balıkçı Gemilerinde İSG Kontrol Listesi' bu çalışmadaki balıkçı teknelerinde kullanılan araç ve gereçlere göre uyumlaştırılarak kullanılmıştır. Listede 13 kategoride gemiye biniş ve inişler (4 adet soru), güvertedeki genel çalışmalar (10 adet soru), kullanılan ağları atma ve sarma operasyonu ( 9 adet soru), ağ makarası ile yapılan faaliyetler (7 adet soru), vinç ve halat ile yapılan faaliyetler ( 7 adet soru), yakalanan balığın taşıyıcı gemiye alınması ya da limana çıkarılması (6 adet soru), hasarlı donanımın tamiri (5 adet soru), kaptan köşkü (5 adet soru), gemi mutfağı/lavabo (5 adet soru) yatakhane ( 8 adet soru), makine dairesi (17 adet soru), geminin iskeleye bağlanması (4 adet soru) ve gemi güvenliği (7 adet soru) olmak üzere toplam 94 soru bulunmaktadır. İlgili liste Ek-1'de verilmiştir. Bu çalışma Çanakkale ilinde faaliyette bulunan 4 balık avlama teknesi ve 2 özel teknede uygulanmıştır. Tekneler A, B, C, D, E ve F olarak isimlendirilmiştir. Araştırma tekne kaptanları ile yüz-yüze görüşülerek ve teknelerde gerçekleştirilen faaliyetler Elmeri gözlem yöntemi ile incelenerek uygulanmıştır.

Çalışma için 19/08/2021 tarih ve E-84026528-050.01.04-2100142987 sayı ile Çanakkale Onsekiz Mart Üniversitesi Lisansüstü Eğitim Enstitüsü Etik Kurulu tarafından onay alınmıştır.

\section{1. Elmeri Gözlem Yöntemi}

Elmeri Gözlem Yöntemi, Finlandiya'da 1990’lı yıllarda temelde imalat sanayii için tasarlanan işyerlerinin güvenlik endekslerini ölçen, anlaşılması ve uygulanması kolay bir saha gözlem yöntemdir (Karabulut, 2016). Elmeri gözlem yöntemi, hem çalışma koşullarını hem de çalışan davranışlarını inceleyen bir temele dayanmaktadır (Ersoy ve 
Yeşilkaya, 2016). Elmeri gözlem yöntemi, İSG performansını ölçebilen ve kazaların potansiyel nedenlerini gösterebilen proaktif bir yöntemdir (Ongun ve Bilen, 2016). Performans gelişimi için gerekliliklerin tespitinde, hedeflerin saptanmasında ve İSG alanında yapılan çalışmaların sonuçlarının ölçülmesine yardımcı olmaktadır (Özdemir, 2014).

Gözlem yöntemi, gözlem için seçilen alanlardaki insan davranışları, makine-ekipman hareketleri ve ortam koşullarını kapsar (Laitinen vd., 2013). Gözlemlenen maddeler Elmeri gözlem yöntemi kurallarını karşılaması halinde "uygun" karşılamadığı durumlarda "uygun değil" değerlendirilir. Puan verilemeyen bir madde varsa "gözlem yok" şeklinde belirtilir (Vahapassi vd., 2012). Gözlem sonucunda işyeri güvenlik endeksi hesaplanır. İşyeri güvenlik endeksleri yüzdelik (\%) değer ile ifade edilerek 0-100 arasında gösterilmektedir (Yaylalı, 2016). İşyeri güvenlik endeksi uygun maddelerin gözlemlenen tüm maddelere oranının yüz ile çarpılması sonucu hesaplanır. Güvenlik endeksi \%80 olarak tespit edilen işyerinde, her 100 İSG unsurundan 80'nin ISG bakımından iyi uygulama olduğunu göstermektedir (Laitinen ve Paivarinta, 2010; Laitinen ve Ruohomaki, 1996). İSG yönetim sisteminin etkinliğini sayisal verilerle ölçen Elmeri yöntemi, düzeltici-önleyici faaliyet adımlarının ölçülmesine yardımcı olmaktadır (Sarıkaya ve Altındağ, 2015). Ayrıca Elmeri gözlem yöntemi İSG eğitimlerini dolaylı olarak destekleyen bir sistemdir. Düzenli İSG eğitimi ile yüksek Elmeri güvenlik indeksi arasında doğrudan bir ilişki bulunmuştur (Sarı ve Kuzupınar, 2017).

Araştırmada 'Balıkçı Gemilerinde İSG Kontrol Listesi' maddeleri kullanılarak teknelerin Elmeri güvenlik endeksleri hesaplanmış ve karşılaştırması yapılmıştır.

\section{Araştırma Bulguları}

Balıkçı gemilerinin faaliyetleri 03.11.01 NACE koduna [Deniz ve kıyı sularında yapılan balıkçılık (gırgır balıkçılığı, dalyancılık dahil)] sahip olup İş Sağlığı ve Güvenliğine İlişkin Tehlike Sınıfları tebliğine göre "Tehlikeli İşler" sınıfında yer almaktadır (İş Sağlığı ve Güvenliği, 2012). Bu nedenle balıkçılık faaliyetlerinin yürütüldüğü teknelerde İş Sağlığ1 ve Güvenliği mevzuatının uygulandığı, çalışanlara ve çevreye karşı tehlike arz etmeyen ya da risklerin minimuma indirildiği çalışma ortamlarının oluşturulması şarttır. Araştırmaya katılan teknelerde yapılan gözlem fotoğrafları Ek-2'de sunulmuştur. Altı balıkçı teknesinde yapılan gözlemler sonucunda, toplam 94 adet sorunun bulunduğu balıkçı gemilerinde İSG kontrol listesine ait bulgular, 13 ana başlık altında verilmiştir.

\section{1. Gemiye Biniş ve İnişler}

Gemiye biniş ve inişler kategorisinde yapılması gereken ve teknelerde yapılan doğru gözlem sayıları ile Elmeri güvenlik endeksleri Tablo 1'de verilmiştir.

Tablo 1. Gemiye Biniş ve İnişler Kategorisinde Yapılması Gereken ve Teknelerde Yapılan Doğru Gözlem Sayıları ile Elmeri Güvenlik Endeksleri

\begin{tabular}{|c|c|c|c|c|c|c|c|}
\hline Gemiye Biniş ve İnişler Alt Kategorileri & Uygun & $\begin{array}{c}\text { A } \\
\text { Teknesi } \\
\text { Uygun }\end{array}$ & $\begin{array}{c}\text { B } \\
\text { Teknesi } \\
\text { Uygun }\end{array}$ & $\begin{array}{c}\text { C } \\
\text { Teknesi } \\
\text { Uygun }\end{array}$ & $\begin{array}{c}\text { D } \\
\text { Teknesi } \\
\text { Uygun }\end{array}$ & $\begin{array}{c}\mathrm{E} \\
\text { Teknesi } \\
\text { Uygun }\end{array}$ & $\begin{array}{c}\mathrm{F} \\
\text { Teknesi } \\
\text { Uygun }\end{array}$ \\
\hline Merdiven veya İskele Kullanılması & 1 & 1 & 1 & 1 & 0 & 1 & 1 \\
\hline Yetersiz Aydinlatma & 1 & 1 & 1 & 0 & 1 & 1 & 1 \\
\hline Engeller & 1 & 1 & 0 & 0 & 1 & 1 & 1 \\
\hline Diğer & 1 & 0 & 0 & 0 & 0 & 0 & 0 \\
\hline Elmeri Güvenlik Endeksi (\%) & 100 & 75 & 50 & 25 & 50 & 75 & 75 \\
\hline
\end{tabular}

Tablo 1'e göre, araştırmaya katılan tüm teknelere biniş ve inişlerinde kullanılan iskelelerin sabitlendiği, kayma veya düşme riskini önleyecek şekilde tasarlandığı tespit edilmiştir. Sadece D teknesinde kullanılan iskelenin rutin kontrollerinin yapılmadığı görülmüştür. Teknelerde bütün alanlar iyi aydınlatılmış, aydınlatma için yeterli miktarda ampul bulunmakta ve pencereden kaynaklanan göz kamaştırıcı riskler önlenmiştir ancak $\mathrm{C}$ teknesinde yanmayan ampullerin bulunduğu gözlemlenmiştir. Biniş ve iniş güzergahındaki engeller tüm teknelerde kaldırıldığı ve acil durum geçiş güzergahlarının açık tutulduğu gözlemlenmiştir. B ve C teknelerinde ise ağların düzenli istiflenmediği görülmüş̧ür.

\section{2. Güvertedeki Genel Çalıșmalar}

Güvertedeki genel çalışmalar kategorisinde yapılması gereken ve teknelerde yapılan doğru gözlem sayıları ile Elmeri güvenlik endeksleri Tablo 2'de verilmiştir. 
Tablo 2. Güvertedeki Genel Çalışmalar Kategorisinde Yapılması Gereken ve Teknelerde Yapılan Doğru Gözlem Sayıları ile Elmeri Güvenlik Endeksleri

\begin{tabular}{|c|c|c|c|c|c|c|c|}
\hline Güvertedeki Genel Çalışmalar Alt Kategorileri & Uygun & $\begin{array}{c}\text { A } \\
\text { Teknesi } \\
\text { Uygun }\end{array}$ & $\begin{array}{c}\text { B } \\
\text { Teknesi } \\
\text { Uygun }\end{array}$ & $\begin{array}{c}\text { C } \\
\text { Teknesi } \\
\text { Uygun }\end{array}$ & $\begin{array}{c}\text { D } \\
\text { Teknesi } \\
\text { Uygun }\end{array}$ & $\begin{array}{c}\mathrm{E} \\
\text { Teknesi } \\
\text { Uygun }\end{array}$ & $\begin{array}{c}\mathrm{F} \\
\text { Teknesi } \\
\text { Uygun }\end{array}$ \\
\hline Islak ve Soğuk Koşullar & 1 & 1 & 0 & 1 & 1 & 0 & 0 \\
\hline Avın ve Av Teçhizatının Taşınması & 1 & 1 & 1 & 1 & 1 & 1 & 0 \\
\hline Denize Düşme & 1 & 1 & 1 & 1 & 1 & 1 & 1 \\
\hline Güverte Üzerindeki Açıklıklar & 1 & 1 & 1 & 1 & 1 & 1 & 1 \\
\hline Gece Çalışmasında Yetersiz Aydınlatma & 1 & 1 & 1 & 1 & 1 & 1 & 1 \\
\hline Kaygan Güverte & 1 & 1 & 0 & 1 & 1 & 1 & 1 \\
\hline Uzun Çalışma Süreleri & 1 & 1 & 1 & 1 & 1 & 1 & 1 \\
\hline Sigara Tüketimi ve Güvensiz Hareketler & 1 & 1 & 1 & 1 & 1 & 0 & 0 \\
\hline Gürültü & 1 & 1 & 1 & 1 & 1 & 1 & 1 \\
\hline Diğer & 1 & 0 & 0 & 0 & 0 & 0 & 0 \\
\hline Elmeri Güvenlik Endeksi (\%) & 100 & 90 & 70 & 90 & 90 & 70 & 60 \\
\hline
\end{tabular}

Tablo 2'ye göre, B ve F tekne personelleri dışındaki diğer tekne personellerine yağmurlu havalarda kullanabileceği yağmurlukların temin edildiği gözlemlenmiştir. Avlanma sonrası avın ve av teçhizatlarının düzenli olarak temizlendiği ve uygun bölmelerde saklandığı gözlemlenmiştir. Ancak B teknesinde avcılık sonrası 1slak olan güvertenin temizlenmediği gözlemlenmiştir. Tüm tekne güvertelerinde kaymaz boya uygulandığı gözlemlenmiştir ancak $\mathrm{E}$ teknesinde soğuk havalarda buzlanma sorunu önlenememiştir. Tekne personellerinin özellikle avcılık faaliyeti esnasında sigara içmemeleri konusunda ciddi şekilde uyarılmasına rağmen $\mathrm{E}$ ve $\mathrm{F}$ tekne personellerinin avcılık faaliyeti esnasında sigara içtikleri gözlemlenmiştir. F teknesinde avlanan balıkların köpük kasalarda taşınmadığı gözlenmiştir.

\section{3. Kullanılan Ağları Atma ve Sarma Operasyonu}

Kullanılan ağları atma ve sarma operasyonu kategorisinde yapılması gereken ve teknelerde yapılan doğru gözlem sayıları ile Elmeri güvenlik endeksleri Tablo 3'te verilmiştir.

Tablo 3. Kullanılan Ağları Atma ve Sarma Operasyonu Kategorisinde Yapılması Gereken ve Teknelerde Yapılan Doğru Gözlem Sayıları ile Elmeri Güvenlik Endeksleri

\begin{tabular}{|c|c|c|c|c|c|c|c|}
\hline $\begin{array}{l}\text { Kullanılan Ağları Atma ve Sarma Operasyonu } \\
\text { Alt Kategorileri }\end{array}$ & Uygun & $\begin{array}{c}\text { A } \\
\text { Teknesi } \\
\text { Uygun }\end{array}$ & $\begin{array}{c}\text { B } \\
\text { Teknesi } \\
\text { Uygun }\end{array}$ & $\begin{array}{c}\text { C } \\
\text { Teknesi } \\
\text { Uygun }\end{array}$ & $\begin{array}{c}\text { D } \\
\text { Teknesi } \\
\text { Uygun }\end{array}$ & $\begin{array}{c}\text { E } \\
\text { Teknesi } \\
\text { Uygun }\end{array}$ & $\begin{array}{c}\text { F } \\
\text { Teknesi } \\
\text { Uygun }\end{array}$ \\
\hline Avcılık Teçhizatına Kıyafetlerin Takılması & 1 & 1 & 1 & 1 & 1 & 1 & 1 \\
\hline Tehlikeli Güverte Alanları & 1 & 1 & 1 & 1 & 1 & 1 & 1 \\
\hline Yetersiz Aydinlatma & 1 & 1 & 1 & 1 & 1 & 1 & 1 \\
\hline $\begin{array}{l}\text { Gırgır Ağ Atılırken Ağa veya Halatlara } \\
\text { Dolanmış Olmak }\end{array}$ & 1 & 1 & 1 & 1 & 1 & 1 & 1 \\
\hline $\begin{array}{l}\text { Kullanılacak Ağ Atılırken Ağa veya Halatlara } \\
\text { Dolanmış Olmak }\end{array}$ & 1 & 1 & 1 & 1 & 1 & 1 & 1 \\
\hline Kaygan Zemin & 1 & 1 & 1 & 1 & 1 & 1 & 1 \\
\hline $\begin{array}{l}\text { Ağ Donanımlarının Takılması ve Çıkarılması } \\
\text { Sırasında Denize Düşmek }\end{array}$ & 1 & 1 & 1 & 1 & 1 & 1 & 1 \\
\hline $\begin{array}{l}\text { Kaptanın Ağ Toplama veya Atma İşiyle } \\
\text { İlgilenen Personeli Görmemesi }\end{array}$ & 1 & 1 & 1 & 1 & 1 & 1 & 1 \\
\hline Diğer & 1 & 0 & 0 & 0 & 0 & 0 & 0 \\
\hline Elmeri Güvenlik Endeksi (\%) & 100 & 89 & 89 & 89 & 89 & 89 & 89 \\
\hline
\end{tabular}

Tablo 3'e göre, araştırmaya katılan tüm teknelerde avc1lıkta kullanılan malzemelerin kıyafetlere takılması konusunda personellere eğitim verilmiştir. Ağ atma ve sarma operasyonları süresince güverte üzerinde tehlike oluşturabilecek ortamlar sınırlandırılmış ve uyarı levhaları asılmıştır. A $\breve{g}$ donanımların hazırlanması ve kullanılması esnasında denize düşme tehlikesine karşın personeller bilgilendirilmiştir.

\section{4. A $\breve{g}$ Makarası ile Yapılan Faaliyetler}

A $\breve{g}$ makarası ile yapılan faaliyetler kategorisinde yapılması gereken ve teknelerde yapılan doğru gözlem sayıları ile Elmeri güvenlik endeksleri Tablo 4'te verilmiştir. 
Tablo 4. Ağ Makarası ile Yapılan Faaliyetler Kategorisinde Yapılması Gereken ve Teknelerde Yapılan Doğru Gözlem Sayıları ile Elmeri Güvenlik Endeksleri

\begin{tabular}{|c|c|c|c|c|c|c|c|}
\hline $\begin{array}{l}\text { Ağ Makarası ile Yapılan Faaliyetler Alt } \\
\text { Kategorileri }\end{array}$ & Uygun & $\begin{array}{l}\text { A } \\
\text { Teknesi } \\
\text { Uygun }\end{array}$ & $\begin{array}{c}\text { B } \\
\text { Teknesi } \\
\text { Uygun }\end{array}$ & $\begin{array}{c}\text { C } \\
\text { Teknesi } \\
\text { Uygun }\end{array}$ & $\begin{array}{l}\text { D } \\
\text { Teknesi } \\
\text { Uygun }\end{array}$ & $\begin{array}{c}\text { E } \\
\text { Teknesi } \\
\text { Uygun }\end{array}$ & $\begin{array}{c}F \\
\text { Teknesi } \\
\text { Uygun }\end{array}$ \\
\hline $\begin{array}{l}\text { Kontrol Noktasından Ağı İstifleyen Tayfanın } \\
\text { Görülmemesi }\end{array}$ & 1 & 1 & 0 & 1 & 1 & 0 & 0 \\
\hline Eskimiş Kumanda & 1 & 1 & 1 & 1 & 1 & 1 & 0 \\
\hline $\begin{array}{l}\text { Makaranın Boşalması } \\
\text { Matafora Üzerindeki İstinga Halatında }\end{array}$ & 1 & 1 & 1 & 1 & 1 & 1 & 1 \\
\hline $\begin{array}{l}\text { Toplanan Mapaların Mandalına Basılması } \\
\text { Sırasında Güverteden Denize Doğru Eğilerek } \\
\text { Çalışma }\end{array}$ & 1 & 1 & 1 & 1 & 1 & 1 & 1 \\
\hline $\begin{array}{l}\text { Ağ Makarasının Altında Ağ İstifi Yapan } \\
\text { Tayfanın Uygun KKD Kullanmaması }\end{array}$ & 1 & 1 & 0 & 1 & 1 & 1 & 1 \\
\hline $\begin{array}{l}\text { Ağ İstifinde Tekrarlanan Hareketlerin } \\
\text { Yapılması }\end{array}$ & 1 & 1 & 1 & 1 & 1 & 1 & 1 \\
\hline Diğer & 1 & 0 & 0 & 0 & 0 & 0 & 0 \\
\hline Elmeri Güvenlik Endeksi (\%) & 100 & 86 & 72 & 86 & 86 & 86 & 86 \\
\hline
\end{tabular}

Tablo 4'e göre, tüm teknelerde ağ makarası kumandasının kontrolleri yapılmış ve çalışır vaziyette olduğu gözlenmiştir.

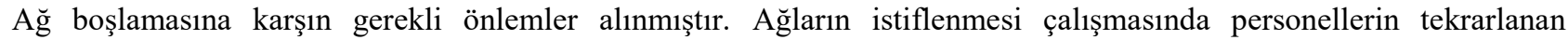
hareketleri yapmasından kaçınması sağlanmıştır. Ağ makarası ile ağ istifi yapan personellere işe uygun kişisel koruyucu donanım sağlanmıştır. Sadece B teknesindeki ağ istifi yapan personellerin kullandığı eldivenlerin yıpranmış olduğu gözlemlenmiştir.

\section{5. Vinç ve Halat ile Yapılan Faaliyetler}

Vinç ve halat ile yapılan faaliyetler kategorisinde yapılması gereken ve teknelerde yapılan doğru gözlem sayıları ile Elmeri güvenlik endeksleri Tablo 5'te verilmiştir.

Tablo 5. Vinç ve Halat ile Yapılan Faaliyetler Kategorisinde Yapılması Gereken ve Teknelerde Yapılan Doğru Gözlem Sayıları ile Elmeri Güvenlik Endeksleri

\begin{tabular}{lccccccc}
\hline $\begin{array}{l}\text { Vinç ve Halat ile Yapılan Faaliyetler Alt } \\
\text { Kategorileri }\end{array}$ & Uygun & $\begin{array}{c}\mathrm{A} \\
\text { Teknesi } \\
\text { Uygun }\end{array}$ & $\begin{array}{c}\text { B } \\
\text { Teknesi } \\
\text { Uygun }\end{array}$ & $\begin{array}{c}\text { C } \\
\text { Teknesi } \\
\text { Uygun }\end{array}$ & $\begin{array}{c}\text { D } \\
\text { Teknesi } \\
\text { Uygun }\end{array}$ & $\begin{array}{c}\text { E } \\
\text { Teknesi } \\
\text { Uygun }\end{array}$ & $\begin{array}{c}\text { F } \\
\text { Teknesi } \\
\text { Uygun }\end{array}$ \\
\hline Korumasız Hareketli Makaralar & 1 & 1 & 1 & 1 & 1 & 0 & 1 \\
Eskimiş Makine Elemanları & 1 & 1 & 1 & 1 & 1 & 1 & 1 \\
Vinç/Halat Operatörünün Güvertedeki & 1 & 1 & 1 & 1 & 1 & 0 & 1 \\
Çalısmayı Görememesi & 1 & 1 & 1 & 1 & 1 & 1 & 1 \\
Yetersiz Acil Durdurma Sistemi & 1 & 1 & 1 & 1 & 1 & 1 & 1 \\
Çelik Halatın Kopması & 1 & 1 & 1 & 1 & 1 & 1 & 1 \\
Frenleme Sisteminin Çalışmaması & 1 & 0 & 0 & 0 & 0 & 0 & 0 \\
Diğer & 100 & 86 & 86 & 86 & 86 & 71 & 86 \\
Elmeri Güvenlik Endeksi (\%) & & & & & & & \\
\hline
\end{tabular}

Tablo 5'e göre, araştırmaya katılan tüm teknelerde vinç fren ve acil durdurma sisteminin çalıştı̆̆ ve kontrollerinin yapıldığ1 gözlenmiştir. Vinç ve halat elemanları rutin olarak kontrol edildiği eskimiş elemanların yenilendiği ve döner aksama sahip makine ve ekipmanların koruyucularının olduğu gözlemlenmiştir. E teknesi operatör kabinin soğuk havalarda camın buğulanmasından dolayı güvertedeki çalışmaları takip edemediği gözlemlenmiştir.

\section{6. Yakalanan Balığın Taşıyıcı Gemiye Alınması ya da Limana Çıkarııması}

Yakalanan balığın taşıyıcı gemiye alınması ya da limana çıkarılması kategorisinde yapılması gereken ve teknelerde yapılan doğru gözlem sayıları ile Elmeri güvenlik endeksleri Tablo 6'da verilmiştir. 
Tablo 6. Yakalanan Balığın Taşıyıcı Gemiye Alınması ya da Limana Çıkarılması Kategorisinde Yapılması Gereken ve Teknelerde Yapılan Doğru Gözlem Sayıları ile Elmeri Güvenlik Endeksleri

\begin{tabular}{lccccccc}
\hline $\begin{array}{l}\text { Yakalanan Balığın Taşıııcı Gemiye Alınması } \\
\text { ya da Limana Çıkarılması Alt Kategorileri }\end{array}$ & Uygun & $\begin{array}{c}\mathrm{A} \\
\text { Teknesi } \\
\text { Uygun }\end{array}$ & $\begin{array}{c}\mathrm{B} \\
\text { Teknesi } \\
\text { Uygun }\end{array}$ & $\begin{array}{c}\mathrm{C} \\
\text { Teknesi } \\
\text { Uygun }\end{array}$ & $\begin{array}{c}\text { D } \\
\text { Teknesi } \\
\text { Uygun }\end{array}$ & $\begin{array}{c}\mathrm{E} \\
\text { Teknesi } \\
\text { Uygun }\end{array}$ & $\begin{array}{c}\mathrm{F} \\
\text { Teknesi } \\
\text { Uygun }\end{array}$ \\
\hline Güvenli Olmayan Güverte Alanı & 1 & 1 & 1 & 1 & 1 & 1 & 1 \\
Tekneler Arası Geçiş & 1 & 0 & 1 & 1 & 1 & 1 & 1 \\
Tekneden Limana Geçiş & 1 & 1 & 1 & 1 & 1 & 1 & 1 \\
Güvenli Olmayan Liman & 1 & 1 & 1 & 0 & 1 & 1 & 1 \\
Kaygan Zemin & 1 & 1 & 1 & 1 & 1 & 1 & 1 \\
Diğer & 1 & 0 & 0 & 0 & 0 & 0 & 0 \\
Elmeri Güvenlik Endeksi (\%) & 100 & 67 & 83 & 67 & 83 & 83 & 83 \\
\hline
\end{tabular}

Tablo 6'ya göre, yakalanan balığın güverte üzerinde nakli esnasında zemin kaygan olması tehlikesine karşın yeterli önlemlerin alındığı gözlemlenmiştir. Tekneler arası ve tekneden limana geçişler konusunda teknelerin bağlantısı sağlanmaktadır. Ancak A teknesinde yakalanan balığın nakli esnasında teknenin halat ile bağlanmadığı tespit edilmiştir. C teknesinin bağlandığı limandaki usturmaçaların ise uygun olmadığı gözlemlenmiştir.

\section{7. Hasarlı Donanımın Tamiri}

Hasarlı donanımın tamiri kategorisinde yapılması gereken ve teknelerde yapılan doğru gözlem sayıları ile Elmeri güvenlik endeksleri Tablo 7'de verilmiştir.

Tablo 7. Hasarlı Donanımın Tamiri Kategorisinde Yapılması Gereken ve Teknelerde Yapılan Doğru Gözlem Sayıları ile Elmeri Güvenlik Endeksleri

\begin{tabular}{lccccccc}
\hline Hasarlı Donanımın Tamiri Alt Kategorileri & Uygun & $\begin{array}{c}\mathrm{A} \\
\text { Teknesi } \\
\text { Uygun }\end{array}$ & $\begin{array}{c}\mathrm{B} \\
\text { Teknesi } \\
\text { Uygun }\end{array}$ & $\begin{array}{c}\mathrm{C} \\
\text { Teknesi } \\
\text { Uygun }\end{array}$ & $\begin{array}{c}\text { D } \\
\text { Teknesi } \\
\text { Uygun }\end{array}$ & $\begin{array}{c}\mathrm{E} \\
\text { Teknesi } \\
\text { Uygun }\end{array}$ & $\begin{array}{c}\mathrm{F} \\
\text { Teknesi } \\
\text { Uygun }\end{array}$ \\
\hline Korkuluk Üzerinden Donanıma Yeti̧̧mek için & 1 & 0 & 1 & 1 & 1 & 1 & 1 \\
Eğilmek & 1 & 1 & 1 & 1 & 1 & 1 & 1 \\
Donanımın Aniden Boşalması & 1 & 1 & 1 & 1 & 1 & 1 & 1 \\
Yıpranmı̧ Çelik Halatlar & 1 & 1 & 1 & 1 & 1 & 1 & 1 \\
Uygun Olmayan Malzemelerin Kullanılması & 1 & 0 & 0 & 0 & 0 & 0 & 0 \\
Diğer & 100 & 60 & 80 & 80 & 80 & 80 & 80 \\
Elmeri Güvenlik Endeksi (\%) & & & & & & & \\
\hline
\end{tabular}

Tablo 7’ye göre, tüm tekneler tekne donanımlarının bakımlarını düzenli olarak yaptırdığı tespit edilmiş̧ir. Yalnızca A teknesinin donanım bakımlarının limanda emniyetli ortamda yapılmadığı gözlenmiştir. Donanımın aniden boşalması riskine karşın gerekli önlemler alınmış, hasarlı ve yıpranmış çelik halatlar kullanım dışı bırakılarak yenisi ile değiştirildiği gözlemlenmiştir.

\section{8. Kaptan Köşkü}

Kaptan köşkü kategorisinde yapılması gereken ve teknelerde yapılan doğru gözlem sayıları ile Elmeri güvenlik endeksleri Tablo 8'de verilmiştir.

Tablo 8. Kaptan Köşkü Kategorisinde Yapılması Gereken ve Teknelerde Yapılan Doğru Gözlem Sayıları ile Elmeri Güvenlik Endeksleri

\begin{tabular}{lccccccc}
\hline Kaptan Köşkü Alt Kategorileri & Uygun & $\begin{array}{c}\text { A } \\
\text { Teknesi } \\
\text { Uygun }\end{array}$ & $\begin{array}{c}\text { B } \\
\text { Teknesi } \\
\text { Uygun }\end{array}$ & $\begin{array}{c}\text { C } \\
\text { Teknesi } \\
\text { Uygun }\end{array}$ & $\begin{array}{c}\text { Teknesi } \\
\text { Uygun }\end{array}$ & $\begin{array}{c}\text { Teknesi } \\
\text { Uygun }\end{array}$ & $\begin{array}{c}\text { F } \\
\text { Teknesi } \\
\text { Uygun }\end{array}$ \\
\hline Uyuya Kalma & 1 & 1 & 1 & 1 & 1 & 1 & 1 \\
Dümenin Başı Boş Bırakılması & 1 & 1 & 1 & 1 & 1 & 1 & 1 \\
Tecrübesizlik & 1 & 1 & 1 & 1 & 1 & 1 & 1 \\
Güverte ile İletişim Eksikliği & 1 & 1 & 1 & 1 & 1 & 1 & 1 \\
Diğer & 1 & 0 & 0 & 0 & 0 & 0 & 0 \\
Elmeri Güvenlik Endeksi (\%) & 100 & 80 & 80 & 80 & 80 & 80 & 80 \\
\hline
\end{tabular}


Tablo 8'e göre, tekne kaptanları ile yapılan görüşmelerde dümenin başı boș bırakılmadığı, güverte üzerindeki personel ile kaptan arasında iletişimin kuvvetli olduğu, kazalara sebep verebilecek uykusuzlukların yaşanmadığı tespit edilmiştir. Ayrıca tekne kaptanlarının yaptıkları işe özgü yeterli resmî belgeleri olmasına ek olarak yeterli tecrübeleri de mevcuttur.

\section{9. Gemi Mutfağı/Lavabo Kullanımı}

Gemi mutfă̆ı/lavabo kullanımı kategorisinde yapılması gereken ve teknelerde yapılan doğru gözlem sayıları ile Elmeri güvenlik endeksleri Tablo 9'da verilmiştir.

Tablo 9. Gemi Mutfağı/Lavabo Kullanımı Kategorisinde Yapılması Gereken ve Teknelerde Yapılan Doğru Gözlem Sayıları ile Elmeri Güvenlik Endeksleri

\begin{tabular}{|c|c|c|c|c|c|c|c|}
\hline $\begin{array}{l}\text { Gemi Mutfağı/Lavabo Kullanımı Alt } \\
\text { Kategorileri }\end{array}$ & Uygun & $\begin{array}{c}\text { A } \\
\text { Teknesi } \\
\text { Uygun }\end{array}$ & $\begin{array}{c}\text { B } \\
\text { Teknesi } \\
\text { Uygun }\end{array}$ & $\begin{array}{c}\text { C } \\
\text { Teknesi } \\
\text { Uygun }\end{array}$ & $\begin{array}{c}\text { D } \\
\text { Teknesi } \\
\text { Uygun }\end{array}$ & $\begin{array}{c}\mathrm{E} \\
\text { Teknesi } \\
\text { Uygun }\end{array}$ & $\begin{array}{c}\mathrm{F} \\
\text { Teknesi } \\
\text { Uygun }\end{array}$ \\
\hline Dağınık Çalışma Alanı & 1 & 1 & 1 & 1 & 1 & 1 & 1 \\
\hline Kaygan Zemin & 1 & 1 & 1 & 1 & 1 & 1 & 1 \\
\hline Hijyen Eksikliği & 1 & 1 & 1 & 1 & 1 & 1 & 1 \\
\hline Gaz Tüpü Kullanımı & 1 & 1 & 1 & 1 & 0 & 1 & 1 \\
\hline Diğer & 1 & 0 & 0 & 0 & 0 & 0 & 0 \\
\hline Elmeri Güvenlik Endeksi (\%) & 100 & 80 & 80 & 80 & 60 & 80 & 80 \\
\hline
\end{tabular}

Tablo 9'a göre, teknelerin ortak kullanım alanları incelendiğinde hijyen kurallarına uyulduğu, mutfak ve lavabolarda hijyeni destekleyen uyarı levhalarının asıldığı gözlemlenmiştir. Ortak kullanım alanlarının düzenli olarak temizlendiği, zemin kaymaya karşı önlem alındığı görülmüştür. Mutfakta tüp kullanımına dikkat edildiği, açık alev ve ateş ile yaklaşılmaması konusunda uyarı levhaları gözlemlenmiştir. Sadece D teknesi mutfağında kullanılan tüpün sabitlenmediği gözlemlenmiştir.

\section{10. Yatakhane}

Yatakhane kategorisinde yapılması gereken ve teknelerde yapılan doğru gözlem sayıları ile Elmeri güvenlik endeksleri Tablo 10'da verilmiștir.

Tablo 10. Yatakhane Kategorisinde Yapılması Gereken ve Teknelerde Yapılan Doğru Gözlem Sayıları ile Elmeri Güvenlik Endeksleri

\begin{tabular}{|c|c|c|c|c|c|c|c|}
\hline Yatakhane Alt Kategorileri & Uygun & $\begin{array}{c}\text { A } \\
\text { Teknesi } \\
\text { Uygun }\end{array}$ & $\begin{array}{c}\text { B } \\
\text { Teknesi } \\
\text { Uygun }\end{array}$ & $\begin{array}{c}\mathrm{C} \\
\text { Teknesi } \\
\text { Uygun }\end{array}$ & $\begin{array}{c}\text { D } \\
\text { Teknesi } \\
\text { Uygun }\end{array}$ & $\begin{array}{c}\mathrm{E} \\
\text { Teknesi } \\
\text { Uygun }\end{array}$ & $\begin{array}{c}\mathrm{F} \\
\text { Teknesi } \\
\text { Uygun }\end{array}$ \\
\hline Dağınık Geçiş ve Zemin & 1 & 1 & 1 & 1 & 1 & 1 & 1 \\
\hline Yetersiz Aydinlatma & 1 & 1 & 1 & 1 & 1 & 1 & 1 \\
\hline Gürültü & 1 & 1 & 1 & 1 & 1 & 1 & 1 \\
\hline Havalandırma ve Sıcaklık & 1 & 1 & 1 & 1 & 0 & 1 & 1 \\
\hline Dar ve Sıkışık Geçiş Yolları & 1 & 1 & 1 & 1 & 1 & 1 & 1 \\
\hline Sigara & 1 & 1 & 1 & 1 & 1 & 1 & 1 \\
\hline $\begin{array}{l}\text { Lavabo, WC, Duş gibi Ortak Kullanım } \\
\text { Alanlarında Hijyen Eksikliği }\end{array}$ & 1 & 1 & 1 & 1 & 1 & 1 & 1 \\
\hline Diğer & 1 & 0 & 0 & 0 & 0 & 0 & 0 \\
\hline Elmeri Güvenlik Endeksi (\%) & 100 & 87 & 87 & 87 & 87 & 87 & 87 \\
\hline
\end{tabular}

Tablo 10'a göre, yatakhanelerde personellerin tertip ve düzen kurallarına uyduğu gözlemlenmiştir. Aydınlatma, havalandırma, sıcaklık, gürültü gibi fiziksel ve termal konfor şartları sağlandığı tespit edilmişstir. Ayrıca yatakhanelerde sigara içilmesi engellenmiş, personellere konu hakkında eğitim verilerek uyarı levhaları ile konu desteklenmiştir.

\section{11. Makine Dairesi}

Makine dairesi kategorisinde yapılması gereken ve teknelerde yapılan doğru gözlem sayıları ile Elmeri güvenlik endeksleri Tablo 11'de verilmiştir.

Tablo 11. Makine Dairesi Kategorisinde Yapılması Gereken ve Teknelerde Yapılan Doğru Gözlem Sayıları ile Elmeri Güvenlik Endeksleri 


\begin{tabular}{|c|c|c|c|c|c|c|c|}
\hline Makine Dairesi Alt Kategorileri & Uygun & $\begin{array}{c}\text { A } \\
\text { Teknesi } \\
\text { Uygun }\end{array}$ & $\begin{array}{c}\text { B } \\
\text { Teknesi } \\
\text { Uygun }\end{array}$ & $\begin{array}{c}\text { C } \\
\text { Teknesi } \\
\text { Uygun }\end{array}$ & $\begin{array}{c}\text { D } \\
\text { Teknesi } \\
\text { Uygun }\end{array}$ & $\begin{array}{c}\mathrm{E} \\
\text { Teknesi } \\
\text { Uygun }\end{array}$ & $\begin{array}{c}\mathrm{F} \\
\text { Teknesi } \\
\text { Uygun }\end{array}$ \\
\hline Zayıf Ulaşım & 1 & 1 & 1 & 1 & 1 & 1 & 1 \\
\hline Yetersiz Aydınlatma & 1 & 1 & 1 & 1 & 1 & 1 & 1 \\
\hline Baş Hizası Engeller & 1 & 1 & 1 & 1 & 1 & 1 & 1 \\
\hline Ana Motorla Temas & 1 & 1 & 1 & 1 & 1 & 1 & 1 \\
\hline Sicak Yüzeyle Temas & 1 & 1 & 1 & 1 & 1 & 1 & 1 \\
\hline Gürültü & 1 & 1 & 1 & 0 & 1 & 1 & 1 \\
\hline Yakıt ve Yağ Sızdırma & 1 & 1 & 1 & 1 & 1 & 1 & 1 \\
\hline Aküler & 1 & 1 & 1 & 1 & 1 & 1 & 0 \\
\hline Elektrik Panoları & 1 & 1 & 1 & 1 & 1 & 1 & 1 \\
\hline Sıkıştırılmış Hava & 1 & 1 & 1 & 1 & 1 & 1 & 1 \\
\hline Hidrofor (Tatlı Su Tankı) & 1 & 1 & 1 & 1 & 1 & 1 & 1 \\
\hline $\begin{array}{l}\text { Aşınmış Borular, Gevşek Bağlantı, Yıpranmış } \\
\text { Contalar }\end{array}$ & 1 & 1 & 1 & 1 & 1 & 1 & 1 \\
\hline Sintine Alarmının Çalışmaması & 1 & 1 & 1 & 1 & 1 & 1 & 1 \\
\hline Tecrübesizlik/Eğitim Eksikliği & 1 & 1 & 1 & 1 & 1 & 1 & 0 \\
\hline Yalnız Çalışma & 1 & 1 & 1 & 1 & 1 & 1 & 1 \\
\hline Yetkisiz Personelin Makine Dairesine Erişimi & 1 & 1 & 1 & 1 & 1 & 0 & 1 \\
\hline Diğer & 1 & 0 & 0 & 0 & 0 & 0 & 0 \\
\hline Elmeri Güvenlik Endeksi (\%) & 100 & 94 & 94 & 88 & 94 & 88 & 82 \\
\hline
\end{tabular}

Tablo 11'e göre, araştırmaya katılan tüm teknelerin makine dairesinde ulaşım yollarının açık olduğu, geçiş yollarındaki aydınlatmanın yeterli olduğu ve baş hizasındaki engellerin yumuşatıcı malzemeler ve uyarı levhaları ile görünür kılındığı tespit edilmiştir. Motorlar, sıcak yüzey ve elektrik panoları ile temas engellenmiştir. C teknesi personellerinin makine dairesinde çalışırken gürültüye karşı kulaklık kullanmadığı gözlemlenmiştir. E teknesi makine dairesine tecrübesiz personellerin geçişinin engellenmediği tespit edilmiştir. F teknesinde kullanılan akülerin emniyetli yerde muhafaza edilmediği gözlemlenmiştir. Ayrıca F teknesinde avlanma tecrübesi olmayan personellerin çalıştığı tespit edilmiștir.

\section{12. Geminin İskeleye Bağlanması}

Geminin iskeleye bağlanması kategorisinde yapılması gereken ve teknelerde yapılan doğru gözlem sayıları ile Elmeri güvenlik endeksleri Tablo 12'de verilmiştir.

Tablo 12. Geminin İskeleye Bağlanması Kategorisinde Yapılması Gereken ve Teknelerde Yapılan Doğru Gözlem Sayıları ile Elmeri Güvenlik Endeksleri

\begin{tabular}{|c|c|c|c|c|c|c|c|}
\hline Geminin İskeleye Bağlanması Alt Kategorileri & Uygun & $\begin{array}{c}\text { A } \\
\text { Teknesi } \\
\text { Uygun }\end{array}$ & $\begin{array}{c}\text { B } \\
\text { Teknesi } \\
\text { Uygun }\end{array}$ & $\begin{array}{c}\text { C } \\
\text { Teknesi } \\
\text { Uygun }\end{array}$ & $\begin{array}{c}\text { D } \\
\text { Teknesi } \\
\text { Uygun }\end{array}$ & $\begin{array}{c}\mathrm{E} \\
\text { Teknesi } \\
\text { Uygun }\end{array}$ & $\begin{array}{c}\mathrm{F} \\
\text { Teknesi } \\
\text { Uygun }\end{array}$ \\
\hline Yetersiz Haberleşme & 1 & 1 & 1 & 1 & 1 & 1 & 1 \\
\hline Halat Atılırken Düşme & 1 & 1 & 1 & 1 & 1 & 1 & 1 \\
\hline $\begin{array}{l}\text { Gemi Tam Olarak Limana Yanaşmadan } \\
\text { Karaya Çıkmaya Çalışmak }\end{array}$ & 1 & 1 & 1 & 1 & 1 & 1 & 1 \\
\hline Diğer & 1 & 0 & 0 & 0 & 0 & 0 & 0 \\
\hline Elmeri Güvenlik Endeksi (\%) & 100 & 75 & 75 & 75 & 75 & 75 & 75 \\
\hline
\end{tabular}

Tablo 12'ye göre, teknelerin iskeleye bağlanması süresince personellerin birbirleri ile iletişimi tam sağladıkları tespit edilmiştir. Özellikle teknenin iskeleye tam yanaşmadan karaya çıkılmaması kuralı tekne personellerince tam anlaşıldığı gözlemlenmiştir.

\section{13. Gemi Güvenliği}

Gemi güvenliği kategorisinde yapılması gereken ve teknelerde yapılan doğru gözlem sayıları ile Elmeri güvenlik endeksleri Tablo 13 'te verilmiştir.

Tablo 13. Gemi Güvenliği Kategorisinde Yapılması Gereken ve Teknelerde Yapılan Doğru Gözlem Sayıları ile Elmeri Güvenlik Endeksleri

$\begin{array}{llllllllllllll}\text { Gemi Güvenliği Alt Kategorileri } & \text { Uygun } & \text { A } & \text { B } & \text { C } & \text { D } & \text { F }\end{array}$




\begin{tabular}{|c|c|c|c|c|c|c|c|}
\hline & & $\begin{array}{l}\text { Teknesi } \\
\text { Uygun }\end{array}$ & $\begin{array}{l}\text { Teknesi } \\
\text { Uygun }\end{array}$ & $\begin{array}{l}\text { Teknesi } \\
\text { Uygun }\end{array}$ & $\begin{array}{l}\text { Teknesi } \\
\text { Uygun }\end{array}$ & $\begin{array}{l}\text { Teknesi } \\
\text { Uygun }\end{array}$ & $\begin{array}{l}\text { Teknesi } \\
\text { Uygun }\end{array}$ \\
\hline Yangin & 1 & 1 & 1 & 1 & 1 & 1 & 1 \\
\hline Acil Durum Alarmlarının Çalışmaması & 1 & 1 & 1 & 1 & 1 & 1 & 1 \\
\hline $\begin{array}{l}\text { Yeterli Sayıda Can Kurtarma Ekipmanlarının } \\
\text { Bulunmaması }\end{array}$ & 1 & 1 & 1 & 1 & 1 & 1 & 1 \\
\hline $\begin{array}{l}\text { Can Kurtarma Salı Kullanma Talimatının } \\
\text { Olmaması }\end{array}$ & 1 & 1 & 1 & 1 & 1 & 1 & 1 \\
\hline Geminin Denize Uygun Koşullarda Tutulması & 1 & 1 & 1 & 1 & 1 & 1 & 1 \\
\hline $\begin{array}{l}\text { Gemi Dengesi ile ilgili Bilgi Dokümanlarının } \\
\text { Gemide Bulunmaması }\end{array}$ & 1 & 1 & 1 & 1 & 1 & 1 & 1 \\
\hline Diğer & 1 & 0 & 0 & 0 & 0 & 0 & 0 \\
\hline Elmeri Güvenlik Endeksi (\%) & 100 & 86 & 86 & 86 & 86 & 86 & 86 \\
\hline
\end{tabular}

Tablo 13'e göre, tekne personelleri yangın konusunda özellikle eğitilmiş ve düzenli tatbikatların yapılması sağlanmışıtır. Ayrıca acil durum alarmı aktif olarak çalışmakta ve tüm tekne personeli acil durum butonu yerini bilmektedir. Teknelerde yeterli sayıda can kurtarma ekipmanlarının olduğu gözlemlenmiştir. Teknelerdeki can kurtarma salı talimatları görünür ve okunaklı olarak asılmıştır. B ve F teknelerinde ise can simidi kullanma talimatı okunamaz halde olduğu tespit edilmiş̧ir.

Çalışmada altı farklı tekneye ait güvenlik endeksi tespitinde Elmeri metodu uygulanmıştır. Teknelere ait genel Elmeri endeksinin yanında, Elmeri içerisinde bulunan kategorilerin ortalamaları da hesaplanmıştır. Altı balıkçı teknesi için ortalama güvenlik endeksleri Şekil 1.’de verilmiştir.

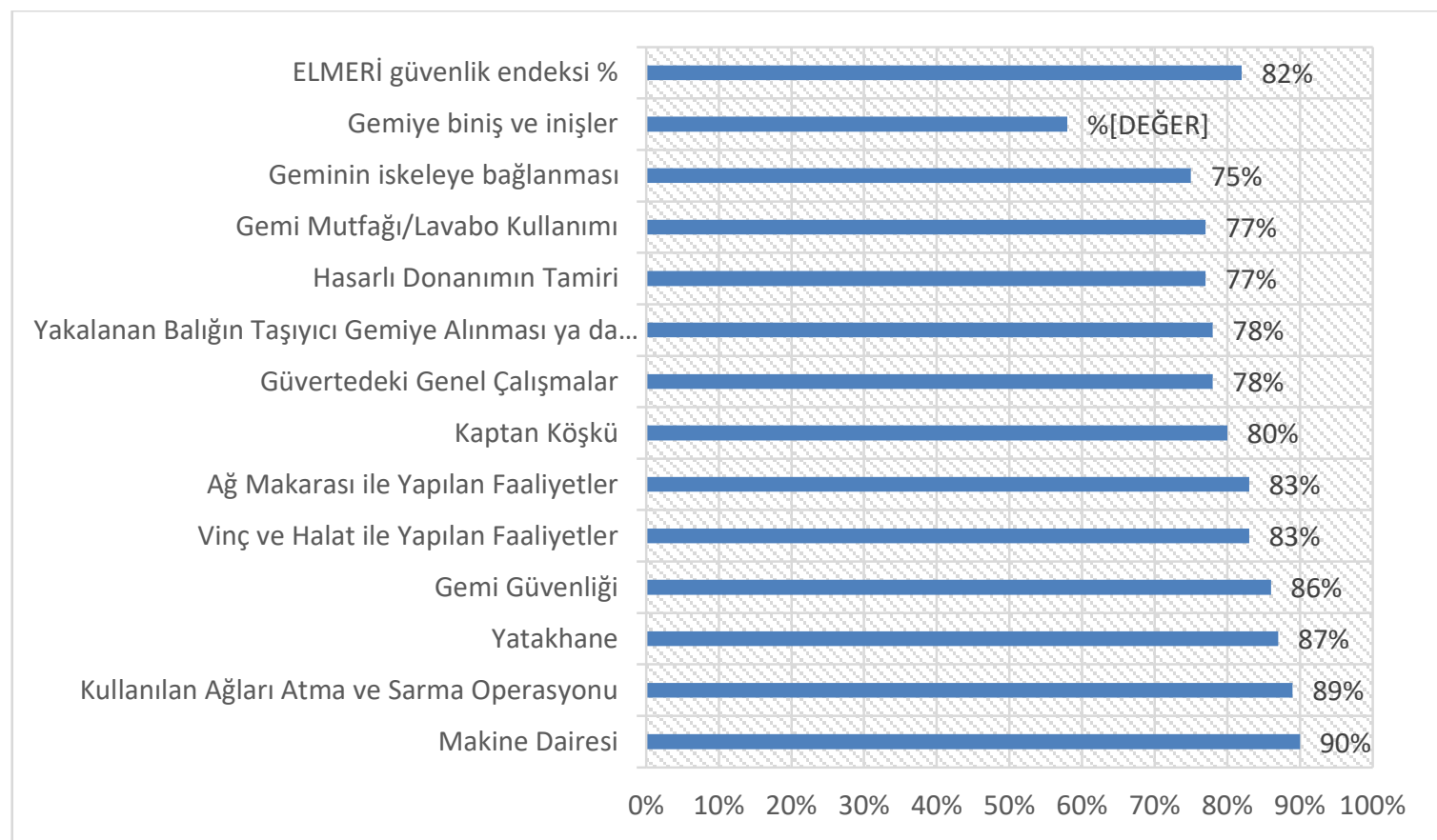

Şekil 1. Konulara Göre Ortalama Elmeri Güvenlik Endeksleri

Şekil 1'e göre; Teknelerin ortalama Elmeri endeks değeri \%82 olarak bulunmuştur. En düşük güvenlik endeksli konu $\% 58$ ile gemiye biniş ve inişler, en yüksek güvenlik endeksli konu $\% 90$ ile makine dairesidir.

\section{Tartışma ve Sonuç}


Altı balıkçı teknesinde, Çalışma ve Sosyal Güvenlik Bakanlığı İş Sağlığı ve Güvenliği Uzmanlık tezinden oluşturulan kontrol listesi kullanılarak Elmeri gözlem yöntemi ile değerlendirildiği çalışmamızda on üç başlık altında incelemeler yapılmıştır.

Bu çalışmada, \%58 ile en düşük Elmeri endeksi olan konu gemiye biniş ve inişler olduğu belirlenmiştir. Tüm teknelere biniş ve inişlerinde kullanılan iskelelerin sabitlendiği, kayma veya düşme riskini önleyecek şekilde tasarlandığı tespit edilmiştir. Sadece D teknesinde kullanılan iskelenin rutin kontrollerinin yapılmadığı görülmüştür. Biniş ve iniş güzergahındaki engeller tüm teknelerde kaldırıldığı ve acil durum geçiş güzergahlarının açık tutulduğu gözlemlenmiştir. Ülkemizde endüstriyel balıkçılık faaliyeti gösteren balıkçı gemilerinde risk değerlendirme yöntemlerinden L tipi matris yöntemi ile yapılan bir çalışmada, gemiye biniş ve inişler konusunda mevcut koruma önlemi bulunmadığı rapor edilmiştir. Gemiye biniş ve inişlerde uygun malzemeden yapılmış ve sağlam olan merdiven veya iskelenin kullanılması gerekliliği rapor edilmiştir (Soykan, 2018). Ülkemizde Karadeniz'de faaliyet gösteren dört balıkçı teknesinin L tipi matris yöntemi ile risk değerlendirmesinin yapıldığı başka bir çalışmada, gemiye biniş ve inişlerde kullanılan iskele ve merdivenlerin orta düzey risk teşkil ettiği rapor edilmiştir (Tantoğlu, 2016).

$\mathrm{Bu}$ çalışmada, vinç ve halat ile yapılan faaliyetler konusunda teknelerin ortalama \%83 Elmeri endeksi aldığ 1 belirlenmiştir. Araştırma sonucunda, tüm teknelerde vinç fren ve acil durdurma sisteminin çalıştığı ve kontrollerinin yetkili personeller tarafından yapıldığı gözlemlenmiştir. Ancak sadece E teknesi operatör kabinin soğuk havalarda camın buğulanmasından dolayı güvertedeki çalışmaları takip edemediği belirlenmiştir. Balıkçı teknesi kazalarının önlenmesi için Birleşik Krallık Deniz Kazaları Araştırma Şubesi (Marine Accident Investigation Branch) çalışmalarının incelendiği bir araştırmada, özellikle vinç operatörlerinin uygunsuz görüş açısından kaynaklı kazaların meydana geldiği rapor edilmiştir. Bu tarz durumlarda özellikle vinç acil durdurma butonunun çalışması ve vinç bakımlarının düzenli yapılması gerekliliği rapor edilmiştir Lang (2002). Ülkemizde Karadeniz'de faaliyet gösteren dört balıkçı teknesinin İSG yönünden incelendiği bir çalışmada, üç balıkçı teknesinin acil durdurma butonlarının çalışmadığı rapor edilmiştir. Araştırmaya katılan balıkçı teknelerinde, çelik halatın kopması ve vinç operatörünün güverte üzerindeki personelleri görememesi gibi risklerin mevcut olduğu da rapor edilmiştir (Tantoğlu, 2016).

Bu çalışmada, gemi güvenliği konusunda teknelerin ortalama \%86 Elmeri endeksi aldığı belirlenmiştir. Tüm teknelerde tekne dengesi ile ilgili resmi belgelerin bulunduğu gözlemlenmiştir. Ülkemizde Karadeniz'de faaliyet gösteren dört balıkçı teknesinin L tipi matris yöntemi ile risk değerlendirmesinin yapıldığı bir çalışmada, 3 balıkçı teknesinin teknelerin denge ile ilgili resmi belgelerin bulunduğu, 1 balıkçı teknesinin bu belgeye sahip olmadı $\breve{g ̆}_{1}$ rapor edilmiştir. Ayrıca tekneye sonradan yapılabilecek tadilatların, tekne dengesini bozabileceğine dair bilgilendirmenin hiçbir personele yapılmadığı rapor edilmiştir (Tantoğlu, 2016). Kanada'da balıkçı teknelerinin kazalarının incelendiği bir çalışmada, balıkçı teknelerinin batma sebebinin yaklaşık \% 75'inin teknelerin dengesi ile alakalı olduğu rapor edilmiştir. Bir çok kaptan ve mürettebatın teknelere yapılan tadilatların tekne dengesini bozacağını düşünmedikleri ve konu hakkında herhangi bir rehbere sahip olmadıklarını beyan ettikleri rapor edilmiştir (Ayeko, 2002).

$\mathrm{Bu}$ çalışmada, güvertedeki genel çalışmalar konusunda teknelerin ortalama \%78 Elmeri endeksi aldığı belirlenmiştir. Araştırma sonucunda, tüm tekne personellerinin uzun çalışma süresine maruz kalmadıkları gözlemlenmiştir. Ülkemizde Karadeniz'de faaliyet gösteren dört balıkçı teknesinde yapılan araştırmada, balık avcılığı için kota sisteminin uygulanmamasından kaynaklı balıkçı teknelerinin yarış içerisine girdiği rapor edilmiştir. Bu durum sonucunda uzun çalışma sürelerinin kaza olasılığını arttırdığı rapor edilmiştir (Tantoğlu, 2016). 1990'larda Amerika Birleşik Devletleri'nde endüstriyel balıkçılık faaliyetleri ile ilgili kota sistemine geçilmesi sonucunda kazaların ve gemi kayıplarının azaldığı rapor edilmiştir. Kota sistemi sayesinde personellerin uzun çalışma sürelerinin düzene girdiği rapor edilmiştir (Craig, 2014). Bu çalışmada tekne personellerinin özellikle avcılık faaliyeti esnasında sigara içmemeleri konusunda ciddi şekilde uyarılmasına rağmen $\mathrm{E}$ ve $\mathrm{F}$ tekne personellerinin avcılık faaliyeti esnasında sigara içtikleri gözlemlenmiştir. Ülkemizde Karadeniz'de faaliyet gösteren dört balıkçı teknesinde yapılan araştırmada, balıkçıların avcılık faaliyetinde bile sigara tükettikleri rapor edilmiştir (Tantoğlu, 2016). Ülkemizde Ege Denizi'nde faaliyet gösteren küçük ölçekli balıkçı teknelerinde İSG'nin değerlendirildiği bir çalışmada, denizde geçirilen uzun sürelerden kaynaklı sigara ve alkol tüketiminin fazla olduğu rapor edilmiştir (Percin vd., 2012).

$\mathrm{Bu}$ çalışmada, yakalanan balığın taşıyıcı gemiye alınması ya da limana çıkarılması konusunda teknelerin ortalama \%78 Elmeri endeksi aldığı belirlenmiştir. Tekneler arası ve tekneden limana geçişler konusunda teknelerin bağlanması sağlandığı belirlenmiştir. Sadece A teknesinde yakalanan balığın nakli esnasında, halat ile bağlantının tekneler arası yapılmadığı tespit edilmiştir Ülkemizde su ürünleri tesislerinin İSG açısından incelendiği bir çalışmada, yakalanan balığın nakli esnasında personellerin iki tekne arasında sıkışmaması için teknelerin baş ve kıç kısımlarından bağlanması gerekliliği rapor edilmiştir (Şık, 2017).

Elde edilen veriler gemiye iniş ve binişlerdeki eksiklikler üzerine yoğunlaşmıştır. Bunun sebebi gemi adamları için gemiye iniş ve binişlerde yeterli düzeyde güvenli geçişlerin sağlanmamasından ve iniş ve biniş güzergahındaki ulaşım yollarının engellerden arındırılmamasından kaynaklanabilir. Bahsedilen sorun, gemiye iniş ve binişlerde uluslararası standartlara uygun iskele veya merdiven temin edilmesi, temin edilecek iskele veya merdivenin rutin bakımlarının yapılması ile çözülebilir. Avcılık gibi tehlikeli faaliyetlerde İSG'nin sağlanması sadece malzeme ve ekipmana bağlı olmamaktadır. Gemi personellerinin mesleki riskler konusunda bilgilendirilmesi ve bu risklere karşı farkındalığın 
arttırılması ile kaza riski en aza düşürülebilir. Bu nedenle Liman başkanlıkları tarafından düzenli aralıklar ile denizcilik faaliyetlerinde İSG konulu seminerlerin düzenlenmesi güvenlik kültürünün pekiştirilmesinde faydalı olacaktır.

Araştırma sonucunda tüm sanayii sektörlerinde kullanılan Elmeri gözlem yönteminin balıkçı teknelerinde de kullanılabileceğini göstermektedir.

\section{Kaynaklar}

Ayeko, M., (2002). Causes and Contributing Faztors - Analysis of accident involving fishing vessels in Canada. Proceedings of the International Fishing Industry Safety and Health Conference. U.S.A., pp.197-210.

Bansal, S., Selvik, J. T., (2021). Investigating the implementation of the safety-diagnosability principle to support defence-in-depth in the nuclear industry: A Fukushima Daiichi accident case study. Engineering Failure Analysis, (123), 1 - 14. https://doi.org/10.1016/j.engfailanal.2021.105315

Bilir, N., (2016). İs Să̆lı̆̆l ve Güvenliği Profili Türkiye, Ankara, Çalışma ve Sosyal Güvenlik Bakanlığı.

Bütüner, S., (2008). Muğla bölgesi endüstriyel balıkçı teknelerinin yapısal özelliklerinin araştırılması, Yüksek Lisans Tezi, Muğla Üniversitesi, Muğla.

Camkurt, M. Z., (2007). İşyeri çalışma sistemi ve işyeri fiziksel faktörlerinin iş kazaları üzerindeki etkisi. TÜHIS $\dot{I} S ̧$ Hukuku ve İktisat Dergisi, 20(6), 80 - 106. http://www.tuhis.org.tr/upload/dergi/cilt20_21_sayi6-1_bolum5.pdf

ÇASGEM (Çalışma ve Sosyal Güvenlik Bakanlığı)., (2017). Türkiye'de Iş Să̆lı̆̆ ve Güvenliği Algısı Araştırma Raporu, Ankara, Çalışma ve Sosyal Güvenlik Bakanlığı.

Craig, B., (2014). Commercial Fishing Vessel Safety and The National Marine Fisheries Service- United States Coast Guard Memorandum on Observer Safety, U.S.A., Report to the National Observer Program National Marine Fisheries Service.

Dalyan, O., Canpolat, E., Dalyan, H., Öztürk, Ö., Pişkin, M., (2021b). Investigation of Under-Reporting of Occupational Accident in Turkey. Karaelmas Journal of Occupational Health and Safety, 5(2), 121 - 132. https://doi.org/10.33720/kisgd.954724

Dalyan, O., Özkaya, N., Pişkin, M., Öztürk, Ö., (2021a). Investigation and Comparison of Some Laboratories in Terms of Occupational Health and Safety by ELMERI Observation Method. Journal of Advanced Research in Natural and Applied Sciences, 7(2), 282 - 294. https://doi.org/10.28979/jarnas/903664

Dalyan, O., Pişkin, M., (2020). İşyerlerinde Ramak Kala Bildirimlerinin İş Kazalarına Etkisi ve İnşaat Sektöründe Uygulama. Çanakkale Onsekiz Mart Üniversitesi Fen Bilimleri Enstitüsü Dergisi, 6(1), 133 - 143. https://10.28979/comufbed.609675

Davis, M.E., (2012). Perceptions of occupational risk by US commercial fishermen. Marine Policy, $36(1), 28$ - 33. https://doi.org/10.1016/j.marpol.2011.03.005

Denizde Can ve Mal Koruma Hakkında Kanun, Kanun Numarası: 4922, Kabul Tarihi: 10/6/1946, Yayımlandığı R. Gazete Tarihi: 14/6/1946 Sayı: 6333, Yayımlandığı Düstur: $\quad$ Tertip: $3 \quad$ Cilt: 27. https://www.resmigazete.gov.tr/arsiv/6329.pdf

Ersoy, M., Yeşilkaya, L., (2016). Comparison of the occupational safety applications in marble quarries of Carrara (Italy) and Iscehisar (Turkey) by using Elmeri method. International Journal of Injury Control and Safety Promotion, 23(1), 29 - 63. https://doi.org/10.1080/17457300.2014.945.464

Estrada, M., (1996). Primary production in the northeastern Mediterranean. Scientia Marina, 60 (Supl. 2), 55 - 64. https://www.researchgate.net/publication/247245963_Primary_production_in_the_northwestern_Mediterranean

Heinrich, H.W., (1959). Industrial Accident Prevention, A Scientific Approach, New York, McGraw-Hill Book Company

İş Sağlığı ve Güvenliğine İlişkin İşyeri Tehlike Sınıfları Tebliği. (2012). Resmi Gazete Tarihi: 26/12/2012. Resmi Gazete Sayıs1: 28509. https://www.resmigazete.gov.tr/eskiler/2012/12/20121226-11.htm

Karabulut, M., (2016). Üniversitelerin kimya laboratuvarlarında çalışanların İSG risklerinin tespiti ve kimyasal maruziyetinin çözüm önerileri, İş Sağlığı ve Güvenliği Uzmanlık Tezi, Çalışma ve Sosyal Güvenlik Bakanlığı, Ankara. meryemkarabulut.pdf (ailevecalisma.gov.tr)

Laitinen, H., Paivarinta, K., (2010). A new-generation safety contest in the construction industry-a long-term evaluation of a real-life intervention. Safety Science, 48(5), 680 - 686. https://doi.org/10.1016/j.SSCI.2010.01.018

Laitinen, H., Ruohomaki, I., (1996). The effects of feedback and goal setting on safety performance at two construction sites. Safety Science, 24(1), 61 - 73. https://doi.org/10.1016/S0925-7535(96)00070-7 
Laitinen, H., Vuorinen, M., Simola, A., Yrjanheikki, E., (2013). Observation-based proactive OHS outcome indicatorsvalidity of the Elmeri+ method. Safety Science, 54, 69 - 79. https://doi.org/10.1016/j.ssci.2012.11.005

Lang, J. S., (2002). Fishing vessel safety - A marine accident investigator's perspective. Proceedings of the International Fishing Industry Safety and Health Conference. U.S.A., pp.67-74.

Limanlar Kanunu, Kanun Numarası: 618, Kabul Tarihi: 14/4/1341, Yayımlandığı R. Gazete Tarihi: 20/4/1341 Sayı: 95, Yayımlandığı Düstur: Tertip: 3 Cilt: 6. https://www.mevzuat.gov.tr/MevzuatMetin/1.3.618.pdf

Nişancı, Z. N., Demirören, J., (2020). Davranış odaklı iş güvenliği uygulamalarının iş güvenliği kültürüne etkisi. Yaşar Üniversitesi E-Dergisi, 15, 21 - 19. https://doi.org/10.19168/jyasar.653821

Öçal, M., Çiçek, Ö., (2017). Türkiye ve Avrupa Birliği'nde iş kazası verilerinin karşılaştırılmalı analizi. HAK-IŞ Uluslararası Emek ve Toplum Dergisi, 6(16), 616 - 637. https://dergipark.org.tr/tr/pub/hakisderg/issue/33300/363789

Ongun, A., Bilen, K., (2016). Elmeri yönteminin incelenmesi ve bu yöntemin bir uygulaması. 8. Uluslararası İş Sağlı̆̆ ve Güvenliği Konferans1. İstanbul, ss. 574 - 583. untitled (ailevecalisma.gov.tr)

Özdemir, B., (2014). Tekstil atölyelerinde iş sağlığı ve güvenliği koşullarının çok ölçütlü karar verme yöntemiyle değerlendirilmesi, İş Sağlığı ve Güvenliği Uzmanlık Tezi, Çalışma ve Sosyal Güvenlik Bakanlığı, Ankara. burakozdemir.pdf (ailevecalisma.gov.tr)

Paolo, F., Gianfranco, F., Luca, F., Marco, M., Andrea M., Francesco, M., Vittorio, P., Mattia, P., Patrizia, S., (2021). Investigating the role of the human element in maritime accidents using semi-supervised hierarchical methods. Transportation Research Procedia, 52, 252-259. https://doi.org/10.1016/j.trpro.2021.01.029

Percin, F., Akyol, O., Davas, A., Saygi, H., (2012). Occupational health of Turkish Aegean small-scale fishermen. Occupational Medicine, 62(2), 148 - 151. https://doi.org/10.1093/occmed/kqr181

Perez-Labajos, C., (2008). Fishing safety policy and research. Marine Policy, $32(1), \quad 40-45$. https://doi.org/10.1016/j.marpol.2007.04.002

Roberts, E.S., (2010). Britain's most hazardous occupation:Commercial fishing. Accident Analysis \& Prevention, 42(1), 44 - 49. https://doi.org/10.1016/j.aap.2009.06.031

Şahin, E., Özekinci, U., (2016). Küçük ölçekli balıkçılığın sosyo-ekonomik durumu, Çanakkale (Kuzey Ege), Türkiye. Çanakkale Onsekiz Mart University Journal of Marine Sciences and Fisheries, 3(1), $19 \quad-\quad 26$. https://doi.org/10.46384/jmsf.740894

Sarı, M., Kuzpınar, H. G., (2017). Aksaray ilinde faaliyet gösteren taş ocaklarında ELMERI® ISG gözlem yöntemi uygulamaları. Uluslararası Maden İşletmelerinde İşçi Sağlığı ve İş Güvenliği Sempozyumu. Adana, ss. 412 - 427. https://www.maden.org.tr/resimler/ekler/8d3eefe2cdb3628_ek.pdf

Sarıkaya, H., Altındağ, R., (2015). Elmeri Yönteminin Mermer Fabrikalarında Uygulanabilirliği. Türkiye 24. Uluslararası Madencilik Kongresi ve Sergisi. Antalya, ss. 90 - 96. https://www.maden.org.tr/resimler/ ekler/5adcde510c66d4c_ek.pdf

Şık, A., (2017). Su ürünleri tesislerinde iş sağlığı ve güvenliği uygulamaları, Yüksek Lisans Tezi, İzmir Katip Çelebi Üniversitesi, İzmir. https://tez.yok.gov.tr/UlusalTezMerkezi

Soykan, O., (2018). Endüstriyel balıkçı gemilerinde L tipi matris yöntemi ile risk değerlendirmesi ve kullanılabilirliği. Su Ürünleri Dergisi, 35(2), 207 - 217. https://doi.org/10.12714/egejfas.2018.35.2.15

Su Ürünleri Kanunu, Kanun Numarası: 1380, Kabul Tarihi: 22/3/1971, Yayımlandığı R. Gazete Tarihi: 4/4/1971 Sayı: 13799, Yayımlandığı Düstur: Tertip: 5 Cilt: 10. https://www.resmigazete.gov.tr/arsiv/13786.pdf

Tantoğlu, G., (2016). Balıkçı gemilerinde yapılan çalışmaların iş sağlığı ve güvenliği yönünden değerlendirilmesi, İş Sağlığı ve Güvenliği Uzmanlık Tezi, Çalışma ve Sosyal Güvenlik Bakanlığı, Ankara. https://www.csgb.gov.tr/media/1433/gururtantoglu.pdf

Ulukan, U., (2016). Balıklar, tekneler ve tayfalar: Türkiye'de balıkçılık sektöründe çalışma ve yaşam koşulları. Çalışma ve Toplum Dergisi, 1, 115 - 142. https://www.calismatoplum.org/makale/baliklar-tekneler-ve-tayfalar-turkiyedebalikcilik-sektorunde-calisma-ve-yasam-kosullari

Vahapassi, A., Laitinen, H., Champbell, S., Ersan, E., Birgören, B., Özesen, M., Matisane, L., Şimșek, C., Atlı, K., Demirkol, D., Rodoplu, S., (2012). KOBİler için iş sağlı̆̆ı ve güvenliği yönetim rehberi: risk dĕgerlendirmesi, ISG performans izleme ve sağllk tehlikeleri-metal sektörü, Ankara, Çalışma ve Sosyal Güvenlik Bakanlığg. Microsoft Word - Metal YENI (ailevecalisma.gov.tr) 
Yaylalı, Ç., (2016). Ișs sağlı̆̆l ve güvenliğinde performans izleme metodu elmeri ve Karamanoğlu Mehmetbey Üniversitesi Teknik Bilimler Meslek Yüksekokulu metal işleri atölyesinde bir uygulama. II.International Multidisciplinary Congress of Eurasia. Odessa, pp. 589 - 602. Önceki Kongreler (imcofe.org)

\section{Teșekkür}

$\mathrm{Bu}$ çalışma Çanakkale Onsekiz Mart Üniversitesi Bilimsel Araştırma Projeleri Koordinasyon Birimi tarafından FYL-2020-3180 nolu proje kapsamında desteklenmiştir.

\section{Conflict of Interest / Çıkar Çatışması}

Yazarlar tarafından herhangi bir çıkar çatışması beyan edilmemiştir.

No conflict of interest was declared by the authors. 